
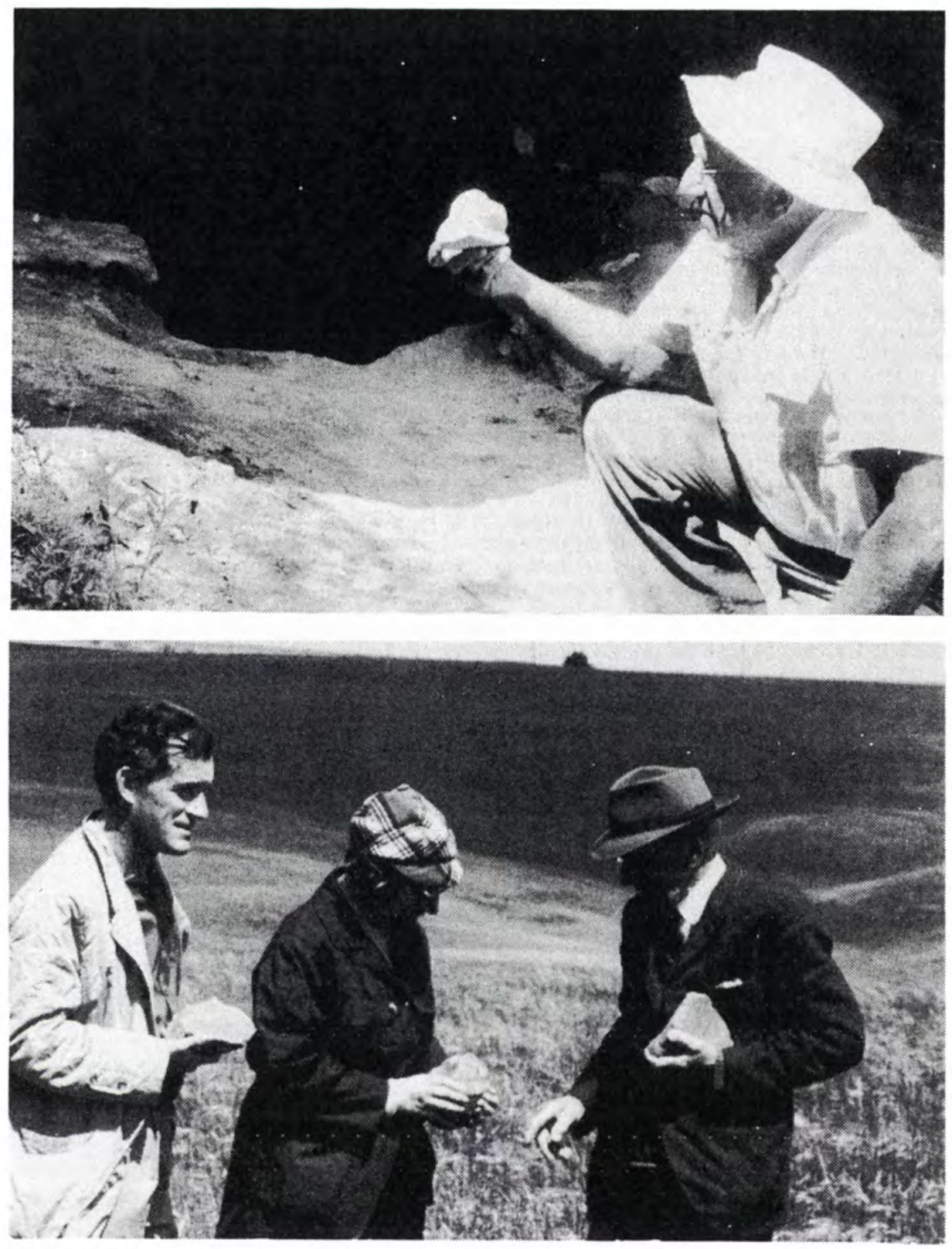

Top: Norman Blunden displaying the Kartan type side-pebble chopping tool from the base of Noola rock shelter a few moments after its excavation, 1 January 1963

Lower: Harold M. Cooper (right) at Hallett Cove, 22 October 1968, displaying new Kartan surface finds to David W.P. Corbett and June Scrymgour of the South Australian Museum

Photographs courtesy of Norman B. Tindale 


\title{
A SOUTH AUSTRALIAN LOOKS AT SOME BEGINNINGS OF ARCHAEOLOGICAL RESEARCH IN AUSTRALIA*
}

\author{
Norman B. Tindale
}

It may be recalled that D.J. Mulvaney suggested that the full porential in Australia of controlled excavation of an archaeological site was first demonstrated in $1929^{1}$ in the excavation at Devon Downs rock shelter (now correctly to be known as Ngautngaut), ${ }^{2}$ situated in the. Miocene marine limestone cliffs of the Lower Murray Valley, in South Australia. Rich stratified occupational deposits were found extending down to a depth of over six metres.

An adjoining open air site on Tartanga Island was found, where surface-eroded, to carry there and in upper layers, some of the small stone tool types found deep in the deposits at Ngautngaut. At Tartanga these upper beds covered several earlier consolidated limy layers denoted as Tartangan, also containing human occupational remains, including mineralised bone and food shells. These layers extended down for two metres to below normal river levels. Implements found in the Tartangan Beds differed in types from ones in the Upper Beds which conformed to ones in the Ngautngaut layers.

When eustatic terrace and radiometric data came to be marshalled, the Ngautngaut sequence was found to extend back to near $5200 \mathrm{BP}$ (Ga-K 1024) while it was evident that the consolidated Tartangan Beds were ones that had been drowned for some two thousand years by the rise of sea level accompanying the Peronian high waters of the interval after $6000 \mathrm{BP}$, following the earlier rise during the Flandrian Recession, marking the end of the Pleistocene and the earlier part of the Recent. Its several beds go down to below $6000 \mathrm{BP}$.

In 1929 the consensus seemed to be that no cultural changes were evident, and that the residence of the Australian Aborigines had not extended far enough back to have affected the ecology of the land. The Murray River finds thus were a direct contradiction of prevailing ideas.

Today the indications of antiquity seem very different. At least two recent finds of Kartan type stone tools, mentioned later in this paper, both derived from shore deposits of the Woakwine marine terrace in the south east of South Australia, may suggest that man has been here at least since the interstadial between Wisconsin I and II Glacial times. Perhaps some of the earliest folk to arrive crossed over the ever present sea barriers dividing Asia from Australia, well before the rise of sea level marking the end of Wisconsin I.

\section{Early studies in archaeology in South Australia}

It should not be forgotten that prior to the finds at Tartanga and Ngautngaut there were much earlier efforts at archaeological exploration, and there were recordings which assumed importance in the light of later studies. As a South Australian, this writer recalls that as early as 1918 he had met Robert H. Pulleine, who, during much

* This paper is based on the Presidential Address given by Dr Tindale to Section 25A (Archaeology) at the ANZAAS Jubilee congress, Adelaide, May 1980. The Editorial Board gratefully acknowledges the co-operation of Dr Grant McCall, who had also invited Dr Tindale to publish his address in Anthropology in Australia: essays to honour 50 years of Mankind (The Anthropological Society of New South Wales, 1982).

Mulvaney 1975:118. See below, p.93.

The South Australian Lands and Survey Department has determined that the name Devon Downs lies on the western side of the Murray River at a distance of some kilometres northward, hence the choice of the original Aboriginal name, Ngautngaut [nautnaut] for the site, as known to the Ngangaruku tribespeople. It was also the name of one of their sinister beings. 
of the next decade, was not only studying mainland Aboriginal sites but also was exploring the Rocky Cape caves in northern Tasmania. However, we understand from his 1929 presidential address to ANZAAS he failed to be convinced of any great antiquity in Australian prehistory and had not found indications of cultural change over the past. A.L. Meston who followed in his footsteps in studying some of the same deposits also failed to see differences.

One early find had been made at Fulham, west of Adelaide, near the coast, in 1893 by Samuel White. It was twenty five years later when his son, Samuel A. White, ${ }^{3}$ reported the discovery of a series of large stone implements during digging to depth in a large area to form a small private lake. They had been found on a land surface underlying marine deposits. Walter Howchin, South Australia's geologist, confirmed the stratification. At the time the find made little impact, but when the Anthropological Society of South Australia was formed in 1926, one of its first team projects was the hand-drilling of a line of holes, each to a depth of five or six metres, from the present coastline to the inner line of reddish sand dunes marking an earlier eustatic terrace, a distance of over a kilometre. Many early members took part in the hand-drilling and recording of the section, using implements loaned by the then Adelaide Electricity Company. This work, continued over months of Saturdays, confirmed the significance of the early find and suggested that what would later come to be known as classic Kartan tools and hammerstones had been made and used far earlier than the small tool types of implements which were present on several campsites well above the former marine bed. In South Australia Howchin had been one of the first systematically to collect and study stone implements, but, surprisingly, despite the Fulham occurrence, he did not look for possibly significant differences in tool types, perhaps because much of the gathering had been done during geological fieldwork in the nineteenth century. In later years any temptation to do so could have been discouraged when his description of supposed eolithic type flints from the Sturt Stony Desert was rejected by others as non-human in origin. At that time Howchin was the only local researcher who had taken part in archaeological work in Europe. As a young geologist in Newcastle-onTyne, he had retrieved relics from early wells along the Roman Wall.

Percival Stapleton was one who had long been interested in rock carvings and modern campsites, particularly in the south east of South Australia where he had spent part of his life. He helped the first members of the newly formed Anthropological Society in many ways. Only in later years was he pursuaded to place some of his observations on record." He was the first to record the worked flints of large size, commonly found near sources of flint along the Port MacDonnell coastline. These have since been established as bifacially knapped blocks of sizes convenient for transport in trade and have been found transported along presumed trade routes as far as 300 kilometres northward from the mining sources. Incidentally, one of his notable finds near Port MacDonnell was a cache of several Polynesian type adze heads, now in the South Australian Museum, perhaps witness to some unrecorded event in our prehistory. Several other seemingly authentic individual finds of such implements have been made in southern Australia and need to be studied.

Harold L. Sheard was a foundation member of the Anthropological Society who also had been interested in rock carvings and paintings. In the days of almost non-existent automobiles, his Ford and a truck borrowed from the Electricity Company were mainstays of much of the teamwork of the Adelaide school. Sheard was the finder of several important rock shelters along the cliffs of the Murray River. Devon Downs (Ngautngaut)

3 S.A. White 1919.

4 Stapleton 1931 and 1945. 
rock carvings were reported first by him..$^{5}$ Although he dug to a depth of somewhat less than a metre, he did not have the good fortune to light upon the considerable depth of occupational deposit further out from the back wall. One other find was a parcel burial of a child wrapped in grass, concealed in a rock crevice where it had become sealed down and preserved by the camping of native opossums over it. After his publication of this find a pirri projectile point was found in the parcel, suggesting that the child had been placed there perhaps more than four thousand years earlier.

Other teamwork by members of the Society was concentrated on known former camping places of the Aborigines, particularly on a large area near the mouth of Pedler Creek on the coast south of Adelaide, a locality later known as Moana. In the mid-1920s Thomas D. Campbell, Herbert M. Hale, Paul S. Hossfeld and this writer spent many weekends studying the surface sites which seemed to be distributed over an area of half a square kilometre of earth rise running down to sand dunes of several 'colours' on the south side of Pedler Creek where it entered the waters of St Vincent Gulf. There was some evidence suggesting that the creek had shifted its lower estuarine reaches progressively northward for several hundred metres during the times when Aborigines had lived there.

The dunes of this area had at one time been well anchored by vegetation, but had begun to be disturbed as visitors came to use the area for recreation during the summer months. What had been a well defined stone walled fishtrap, formed of large quartzite pebbles, had been seriously disturbed by removal of the pebbles, while wind erosion over much of the area was beginning to expose the ashes of former fires, remains of food shells, stone implements, and waste pieces of transported stone. Early in the continuing study it became evident that the soils and sands of some of the areas differed in texture, colour, and degree of compaction, and this writer thought he could detect tool type differences in several parts of the area, although his companions preferred to pool all stone implements they found. To test this the four main areas of evident campsite were marked, using symbols A, B, C, and D, as shown in Figure 1 .

The sites on the southern bank of Pedler Creek (marked as C) appeared to be much younger than the others, with fresh charcoal and ash, and other indications of recent occupation, such as well-charred pieces of wood. Also there were bones of small animals, recognised to be of species known as part of the fauna near Adelaide. Food shells such as unionids from the creek, and Donax cockles from the sea shore, often had their nacre still preserved. Some shallow burials were present. The principal tools were irregular flakes, and stone axe heads were reported to have been found on the surface in places where it was eroded. Later on, our assessment of recency was confirmed when our oldest informant, Milerum of the Tanganekald tribe, led us to the places where, as a boy in the 1870 s, he and his parents had camped while on journeys to Adelaide from their home near the mouth of the Murray River. Milerum also took us to the low wall of rocks which marked the place on the cliffs to the south where older men used to camp during the day, watching for schools of mulloway fish that swam up the Gulf, following the shoreline in the rise of water as it came to break as surf on the shore.

$B$ indicated dunes aligned parallel with the seashore, but up to a hundred metres inland from the present-day beach line. Their sands show a greyish colour rather than the fresh yellowish colour of the creek-side sands. In B the food remains appeared scant since most of the animal remains had decayed. Instead of the irregular, casually-worked flakes of area $\mathrm{C}$ the regular implements of $\mathrm{B}$ were exceedingly well-worked geometric flakes of 


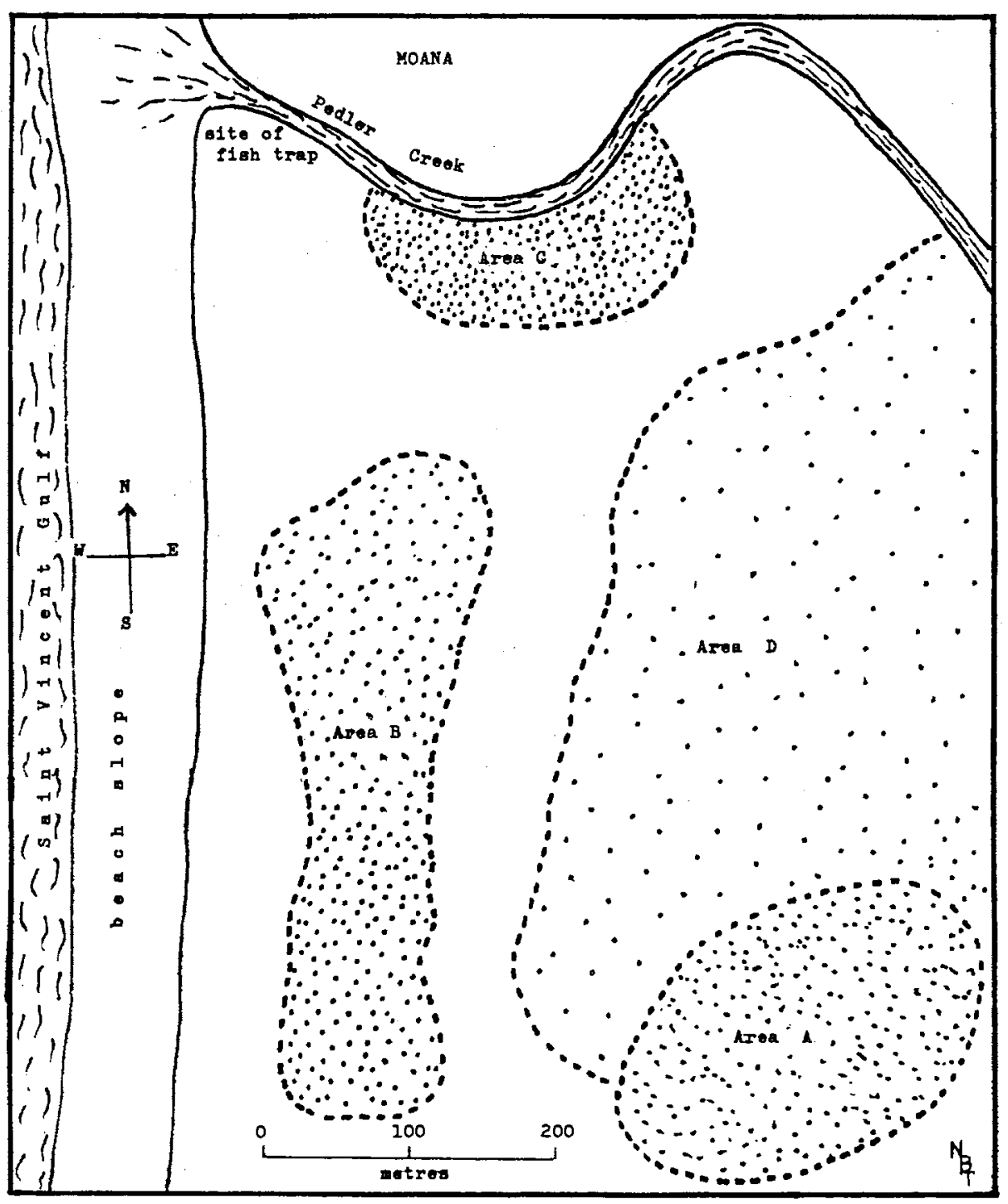

Figure 1. Archaeological sites south of Pedler Creek, Moana, S.A.

small size, including crescents and triangles, together with small discoidal adze stones. The latter were made on prepared flakes bearing a well-defined striking platform. Hammerstones were present.

Area $\mathrm{A}$ to the south continued to yield only some larger well-patinated flakes which at the time did not arouse particular interest.

Generally more than one hundred metres inland from the alignment of the B dunes was a similar, much higher line, at first well-anchored by vegetation. In places where 
erosion had commenced pirri projectile points appeared along with some geometrics. No bone relics seemed to have been preserved. The sands had a distinctly reddish colour. This area was designated as $D$.

At this stage of our study Hossfeld and Campbell, whose special interests were in obtaining series of implements, spent many weekends systematically crawling over the whole area, picking up and taking away all worked pieces present on the surface. This would test whether the supposed differences would be registered again when further erosion took place. During the winter following this effort a series of exceptional gales blew away vast amounts of sand from much of the area under study, thus revealing richer layers of wind-excavated and winnowed occupational debris. Since all significant surface material had been removed each of the four areas provided fresh evidence of the differences which had already been noticed. The inland $D$ dunes continued to yield unifacially worked pirri points in abundance together with some rather poorly worked geometrics. Erosion, partly by water from the slope to the south, revealed some further larger flake tools on A, while the B camps continued to yield the 'good' geometrics and discoidal adze stones. By 1929 therefore, there was some evidence for differentiation in implement types from different sites, but thoughts then of eustatic changes in sea level had not been evaluated seriously, and the succession of types was still a matter of opinion, if indeed there was thought to be a succession.

The excavation of Ngautngaut and Tartanga changed the picture and revealed that there had been a series of changes. Further, since Moana and the Murray River sites were well over 100 kilometres apart, and beyond two present-day tribal boundaries, the changes had taken place on a regional basis. A new field of study had opened. It was realised also that similar stone tools had been collected on eroded desert campsites at distances away exceeding 1000 kilometres, while others were known to be still in use among peoples living equally far away to north and west, and some even had been used on the eastern coast of the continent.

\section{Prehistory in South Australia after Ngautngaut}

For several years after the report on the Murray River excavations had appeared, under the non-committal title of 'Notes on some human remains in the Lower Murray Valley, South Australia', in the Records of the South Australian Museum, ${ }^{6}$ the authors heard relatively little of comment.

This writer continued work on the stratigraphic leads and implications which had been registered. Additional data soon became available. A discovery at Hawks Nest on Kangaroo Island, South Australia's great island, was made by R. G. Thomas in 1930, while conducting a survey for the Commonwealth Nutrition Laboratory in connection with the then newly aroused interest in the effects of cobalt deficiency on mammalian life. His find of many large quartzite pebble tools and hammerstones led at once to a study by W.W. Jolly, B.G. Maegraith and this writer, recovering many hundreds of these tools, spread over an area of several square kilometres on an older series of north-eastern shores of the formerly much larger and now brackish-water lagoon, called Murrell's, after one of the lawless white men who were escapees from Tasmania and lived on the island with their captive Tasmanian Aboriginal wives during the early years of the nineteenth century. 


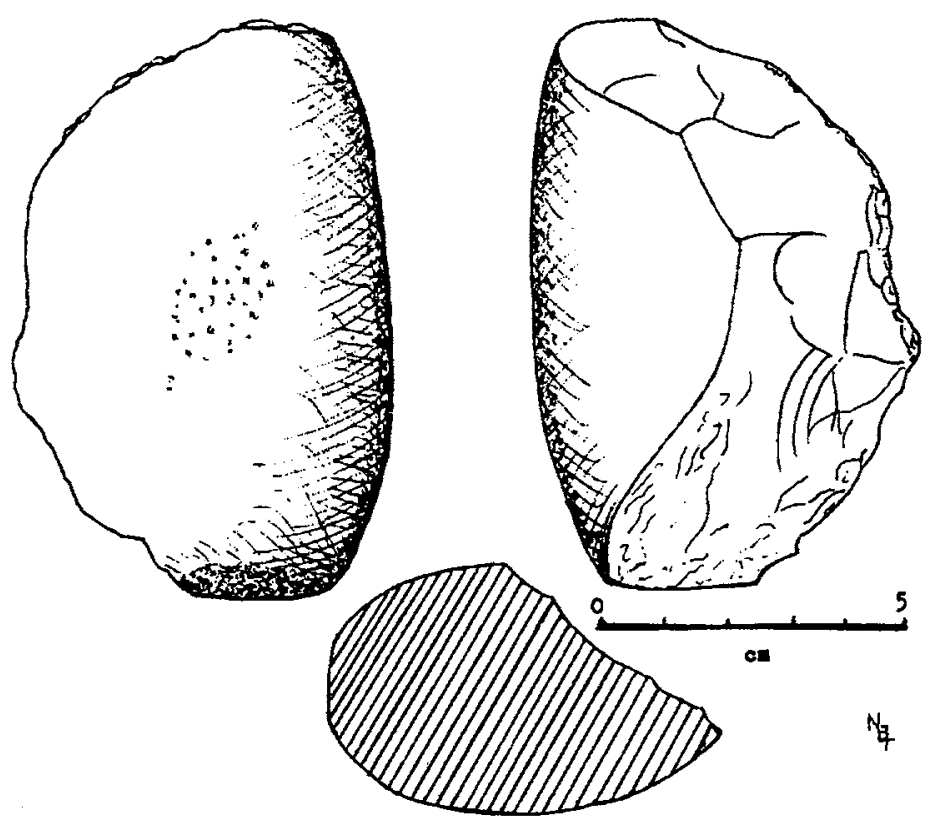

Figure 2. Hammerstone of quartzite reworked as side pebble chopper. Found 8 January 1932, eroded from fresh washout, Rainy Creek, Kangaroo Island. Kartan of Kangaroo Island

The find by Thomas was not the first from Kangaroo Island, since Howchin had already reported hammerstones there, ${ }^{7}$ just a century after explorer Matthew Flinders had discovered the island and found it to be uninhabited. Further fieldwork by this writer with Frederick J. Hall, and with L. Keith Ward of the Mines Department indicated implements in situ (e.g. Figure 2) in pre-coastal-dune stream deposits at Rainy Creek ${ }^{8}$ When Harold M. Cooper (Plate I) became a volunteer helper in the Anthropology Section of the South Australian Museum in 1934 he was assigned as study project the distribution of occupational sites on the Island, where he had a holiday home. He was able to demonstrate the presence of as many as a hundred sites of occupation and confirmed our suspicions that none of the post-Pleistocene coastal dunes had ever been trodden by early man, thus indirectly supporting a link with the pre-marine tools of similar type from Fulham.

Interest in South Australian results became evident in 1935. Frederick D. McCarthy of the Australian Museum, Sydney, was taken to see the Murray River excavations and a few months later Hallam L. Movius of Harvard was escorted over the Kangaroo Island sites. About the same time a letter from J.L. Shellshear of Sydney requested help in stimulating interest in archaeology in New South Wales.

Thus in June 1936, during the first days of a year-long study visit to America and Europe, this writer met with Elsie Bramell, F.D. McCarthy, J. Shellshear and some others at the Australian Museum, Sydney. Detailed discussions took place on methods, the results of work done by Shellshear in South East Asia and the discoveries of P.V. van Stein 
Callenfels. Later a small party viewed the sites of rock carving studies by McCarthy and discussed methods for casting them, as developed in Adelaide. Using a Fisheries Department launch the party searched for possible rock shelter deposits along the cliffs of the Hawkesbury River, and discovered one cave near Cowan Point with some sixty paintings of hands. Shellshear was interested in the technical aspects of our work at Tartanga and elsewhere, and in the telpher line on which excavated material had been run by gravity out of the cave at Kongarati near Second Valley in South Australia. The results of this dig were then going through the press. ${ }^{9}$ They had included discovery of well-preserved post-Mid-Recent materials. Incidentally, this writer, two months later, spent a day at the open air excavations being conducted on the Folsom site at Lindenmeier, Colorado, even locating a projectile point. Still later he handled some of the Callenfels finds in Amsterdam, and spent time attempting to convince M.C. Burkitt in London that unifacially worked flake tools, with well-formed striking platforms, known to us in Australia as tula, and tula slugs, were the same implement, one a lot more used than the other, from being repeatedly knapped in resharpening, while set with resin in a chisel or adze handle. The term scraper was indicated to be a very inappropriate one.

Following return to Australia in 1937 two years were spent in fieldwork shared with Joseph B. Birdsell. While emphasis of the programme was on physical and cultural anthropology, each of the States of Australia were visited and at many field stations archaeological data found. As examples large stone axes with hafting grooves were present archaeologically at Monamona on the Atherton Tableland in northern Queensland. From the Tjapukai tribespeople it was learned that their use had continued up to the present, being hafted, using wrap-around long handles of lawyer cane, and employed in the felling of rain forest trees. Side-pebble chopping tools of seemingly ancient date were present also in the rain forest. Similar side-pebble chopping tools were also found to be present both on Cape Barren and Flinders Islands in Bass Strait, between Australia and Tasmania. Evidence for microlithic industries was present in many places (Figure 3), while pirri, unifacially worked points, were identified as far west as Eucla and well formed geometric ones west to the Gnowangerup district in south-western Australia. A highlight was the finding of what appeared to be a trade parcel of seventy four discoidal flint flakes, each about $6-9 \mathrm{~cm}$ in diameter, in a sand dune site at Eucla. Seemingly these were partly worked pieces brought from a native mine at Wilson Bluff, a few kilometres to the east. These flakes were described by Tindale and Noone, ${ }^{10}$ and it may be of interest to note that a quarter century later, when on several field trips with John Greenway, we visited the mine in the marine cliff. We also recorded, in the Rawlinson Ranges, more than 750 kilometres to the north, a seemingly mythic song cycle which ascribed evil to a turkey bustard being, in stealing fire from man. When successively more southern versions of this myth were collected from the Nakako and more southern tribes this became a recognisable itinerary recounting by name the line of watering places leading deviously across the difficult-totraverse Nullarbor Plain to Wilson Bluff, where two hawk beings had prevented the turkey being from drowning fire flints in the sea. It may even be that this elaborate ceremonial song cycle has preserved a memory of one of the latest effects of the Post-Glacial rise of sea level in the Mid-Recent. Earlier work in north-western Australia and collected among the Nakako had revealed the wide distribution in the Western Desert of the large, rollingpressure finished flake knives now called tjimari, such as are the normal tool of several Desert tribes. It became evident the Eucla hoard had been planned to be timari-like tools. 


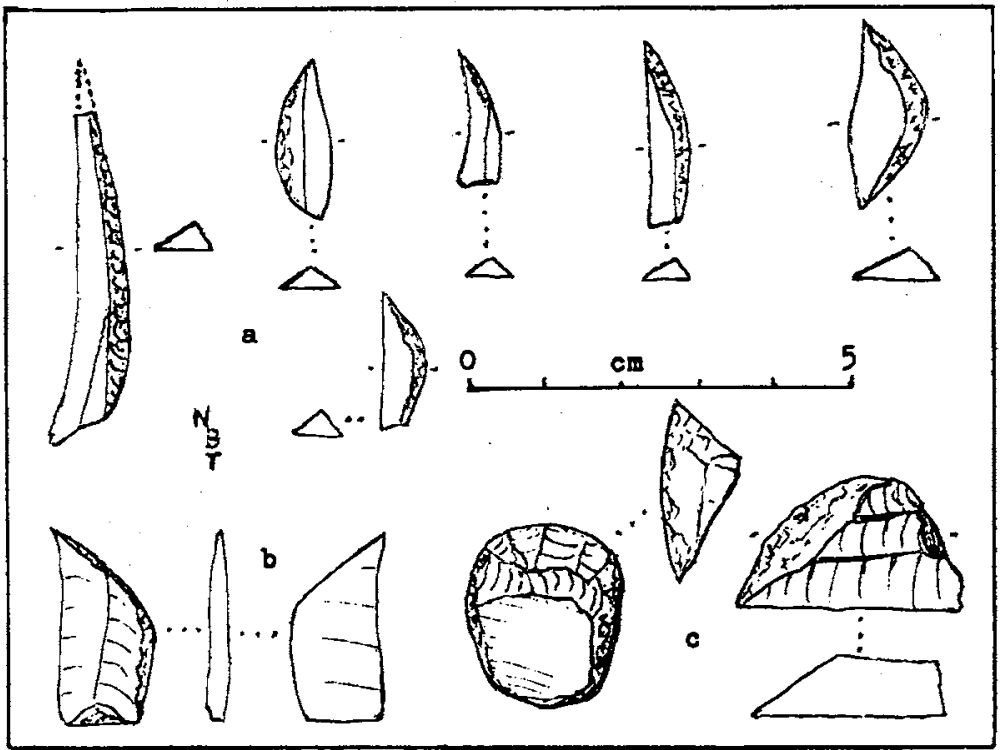

Figure 3. Microlithic implements from the interior of Western Australia, collected by J. B. Birdsell. (a) Site 4. Smithsonia Waters, jasper and quartz crystal (A.44894 in South Australian Museum). (b) Site 16. $100 \mathrm{~km} \mathrm{N.W.} \mathrm{of} \mathrm{Leonora,} \mathrm{coarse} \mathrm{quartzite} \mathrm{(A.45216).} \mathrm{(c)} \mathrm{Site} \mathrm{17.} 19 \mathrm{~km}$ from Wiluna on Meekatharra track, chert and jasper (A.45217). Assessed as Mudukian.

In the last days of the Harvard Expedition in 1939, on the way to western New South Wales, evidence was found of man's presence on the northern shores of the former Lake Menindee, in apparent association with extinct species of large mammals. Actual honours went to the late Dorothy M. Tindale who picked up the first fossil bone. Preliminary studies were made but the onset of World War II delayed further research there for some years. ${ }^{11}$

While preparing an exhibit in the South Australian Museum showing the progress in archaeological discovery, this writer wrote a summary article for the Australian Joumal of Science confirming the sequence and significance of the several culture phases proposed earlier for the Murray Valley sites, and indicated their far wider spread. ${ }^{12}$ In addition, the Kartan culture phase was recognised as the earliest detected in Australia. The name was based on the Ramindjeri tribal name for the mystical island of the dead, lying uninhabited to their south: Karta, our Kangaroo Island. It was noted that the Fulham finds were closely related.

Some useful archaeological work continued during the war period. Beginning in 1940 , South Australia was privileged to have as a long term visitor, H.V.V. Noone, whose knowledge of stone tools stimulated interest, and his guidance and encouragement led to more than one researcher's placing his observations on record. Noone stressed the significance of the microlithic tools. For some years after 1940 South Australian workers 
continued to dominate the field in archaeology but their studies became far-ranging. South Australians found pirri point sites, for example, as far to the north in Queensland as near the Gulf of Carpentaria, and J.B. Birdsell found typical Bondi (Bondai) points at Smithsonia Waters, far inland in Western Australia (Figure 3). During the early $1940 \mathrm{~s}$ members of the Anthropological Society also continued limited fieldwork. H.M. Cooper was hampered by being entrusted with the transfer of the Museum collections for wartime safety to a tunnel located in the Adelaide Hills, but had other opportunities and located several Kartan sites in the Flinders Ranges. H.L. Sheard had earlier found extensive sites at Hatherleigh in the south east of South Australia and others conducted wide surveys in the same area. ${ }^{13}$

On leave after return from overseas duty in 1946, this author spent several weeks in the same area, first following up a report of a find by C.G. Stephens (during soil survey work in the Hundred of Young) of deeply patinated yellow discoidal flakes of formerly black flint, sometimes almost completely changed to chalk, and similar to those of H.L. Sheard. Both sites were assessed as Tartangan. On the same visit the Cape Northumberland site was discovered, later dated as beginning at $1470 \mathrm{BP} .{ }^{14}$ Two days later (17 January 1947), the coastal consolidated dune site (with the same patinated discoidal flints as at Symon and Hatherleigh in situ) was located at Cape Martin. Later these were dated as close to $8700 \mathrm{BP}$. In the absence then of other dating methods this author developed an eustatic terrace study of the area of the south east. ${ }^{15}$

Within a month of the above finds (February 1947) there was a working conference at Millicent where South Australian anthropologists J.B. Cleland, T.D. Campbell, Gwen Walsh, and this writer met with Dermot Casey, R. Keble, and Stanley R. Mitchell of the Victorian group interested in archaeology. This was the first formal meeting between students of the two States. Sites at Bevilaqua Ford, Kongorong, Symon, and Mount Muirhead were examined and eustatic terraces studied. Mitchell illustrated some of the large discoidal and yellow-stained flints from Kongorong (drawn by G. Walsh) ${ }^{16}$ but did not note the fresh microlith-containing layers which lay above them at more than one of these sites. The activities of the conference members were noted in the South Eastern Times of 21 February 1947.

A year later the same South Australian group, with the addition of E. Couper Black and P.S. Hossfeld, met at MacDonnell Bay with S.R. Mitchell. The Cape Northumberland site was confirmed as similar to the 'marniong' mounds of Victoria. The Hood's Drift site at Kongorong was studied in some detail, establishing the presence of the upper microlith bearing bed of classic type, overlying a much earlier horizon with the large discoidal flints which were deeply patinated. ${ }^{17}$ It was on this field study that a site with pirri points was discovered at Middle Point (Section A, Hundred of MacDonnell), the easternmost then known occurrence of such implements. Although it had a deep influence on their thinking, much of this south-eastern work lies unchronicled in the field books of the several researchers, being overshadowed by the 'glamour' of the more ancient discoveries elsewhere.

In 1949 a single pebble side-chopper was found at Carlton, in southeastern Tasmania, thus extending the area of distribution of the. Kartan type from St Helens and the Bass

Campbell, Cleland and Hossfeld 1946.

Tindale 1964:24.

Tindale $1957: 9$ and 1947.

Mitchell 1949:173-174.

Mitchell 1949:173; Tindale 1957, Fig. 24; Tindale I981, Fig. 10a 
Strait Islands. The specimen has recently been figured.$^{18}$ One of the finds in 1950 by H.M. Cooper, important because of its possible sociological significance, was a hoard of some seventy-five elongate-oval slate stones with sets of incised transverse lines. Usually there was a median dividing groove and the number of lines on one half closely approximated the other. A dozen were whole and the rest had been broken more or less in half. Not one of the matching halves was present. This hoard was situated at Yudnapunda Springs in the Flinders Ranges. Kartan type tools were present nearby. Another important discovery was an old Flinders Range Aboriginal of the Wailpi tribe who still used a hunting weapon of his ancestors, a well-worked spherical ball, called mara, (a word elsewhere used for the word 'hand'). White quartz was favoured because of ease of finding after a throw. This implement occurs on Kangaroo Island and on mainland sites of all ages.

One of the highlights of 1951 was the finding of a rich microlith site at Policeman Point (Section 2, Hundred of Santo) on the mainland side of the Coorong on the shore of an old bay which had been cut off from the main estuary by a bank formed when the sea was about two metres higher than at present. It was a one-culture-phase site, clearly a well-developed Mudukian one. The occasion had general historical interest since Anthony N. Sturt, descendant of the Captain Sturt who had explored the Murray River one hundred years earlier, was one of the party, along with Harold A. Lindsay. In later years this site continued to furnish important data. Most of the highly developed microlithic implement types known, including one clear quartz crystal discoidal flake, completely worked and only 6 $\mathrm{mm}$ in diameter, were present on one concentrated area.

In 1952 the University of California (Los Angeles) and Adelaide University Anthropological Expedition began its three years of fieldwork, with J. B. Birdsell and this writer, by gathering material for the radiometric dating of Layer $C$ at Tartanga, later recorded as $6020 \pm$ 120 BP. The Harvard-Adelaide pre-war programme was continued, chiefly in Western Australia and the Northern Territory. The extensive archaeological finds ancilliary to the main endeavours are registered in the South Australian Museum collection, and as circumstances permit are being reported. ${ }^{19} \mathrm{~A}$ useful result was the finding at Moolabulla, in the north west of Western Australia, in an eroded old soil of a solitary, grooved quartzite edgeground axe of the old type. At some time in the past it had been reworked as a chopping tool. ${ }^{20}$ Above it was a sandy soil with numerous unifacially worked pirri points and signs of occupation. The Government Station had been established there and present day Aborigines, who use bifacially pressure-flaked spear points, and not pirri, were also camping there. To the Djaru and Kitja the pirri were " "eagle claws" of the people before'. In filming their pressure flaking techniques it was observed that the initial flakes struck off the cores were similar to pirri blanks, and the cores, brought from more than a day's walk away, were similar to large bifaces found across the continent in the Mount Gambier area of South Australia.

In October 1955 C.S. Ashley presented the South Australian Museum with a series of Mudukian microliths which he had just discovered on a site at the entrance to Koonalda Cave on the Nullarbor Plain. Further specimens were collected there by John Greenway and the writer in October 1965, confirming Ashley's finds. ${ }^{21}$ A. Gallus was directed to the cave and began work in it in January 1957, leading to his remarkable discoveries. ${ }^{22}$

In January 1956 Derek John Mulvaney and a team from Melbourne began the excavation of Fromms Landing shelter on the River Murray, at Walker Flat, thus starting a series of rock shelter and cave diggings which have added much to our detailed knowledge of

18 Tindale 1981 , Fig. 4.

19 Tindale 1957:3 and passim; Tindale 1981. See also Fig. 3 this paper.

Tindale 1981 , Fig. 5.

For an example see Tindale 1981, Fig. 12e.

Gallus 1971 . 
Australia's past. The Fromms Landing results, ${ }^{23}$ at a place only ten kilometres or so south from Ngautngaut, showed little beyond casual differences. Radiocarbon dates indicated that both shelters had been occupied by microlith-using peoples beginning in the MidRecent. Later work on their Site 6 yielded an early specimen of the dingo along with an indication of what turned out to be a women's cooking area.

During the mid-1950s, the Moana area was being studied by this author, chiefly with Harold M. Burrows and in December 1956 with John Greenway of the University of Colorado. It became even clearer from the implements exposed by continued erosion of the sands in the several areas that the campsites on B were definitely linked with the Murray River horizon we had termed Mudukian and that area D further inland was clearly of Pirrian time, since we found many unifacial spear blades, and at one place, we were able to map what appeared to be a man's actual workshop for pirri points with the finished blades still lying in a line where they had been, for some reason abandoned. My interpretation of the site was influenced definitely by the workshop for pressure-flaked spear points I had filmed in 1953 at.Moolabulla, Western Australia, of which a considered account is appearing this year. ${ }^{24}$ It was on one of these study visits that we found, further inland on the surface of eroded kunkar limestone, at an estimated ten metres above sea level, a typical side-pebble chopping tool. ${ }^{23}$ This tool was coated with lime when found and now is specimen a.48749 in the South Australian Museum.

In November 1960 members of the Anthropological Society of South Australia also paid a visit to the Moana site and saw the latest results of the fieldwork begun in 1924. At this time the work at Waldeila campsite (Section 185, Hundred of Willunga) began in 1955 also was exhibited and it became an interest of a member, the late Rodney D.J. Weathersbee, who in 1980 completed an important study. Early finds had indicated that it had been used in microlith times and that pebble choppers, worked on the end, and characteristic of the latest days, were present on the surface.

In 1957, on the suggestion of Hallam L. Movius, who had followed the results being obtained in South Australia, an attempt was made to summarise the several culture phases that had been recognised, from the Recent to Late Pleistocene. ${ }^{26}$ One purpose was to try and prevent the unnecessary duplication of culture marker names, and confirm priorities of those published.

In I957 there began a series of opportunities, through cooperation with the patrol officers of the Woomera Project, to visit then remote areas, such as the Rawlinson Ranges and beyond, in order to develop links with tribespeople who had never been in contact with 'white' people. The work continued into the 1960 s. For archaeology, this led to useful indications that ceremonial arrangements of stones were still living shrines, and that newlymet people still used resin-hafted discoidal stone implements, characteristic of the early Recent in southeastern Australia, as usual tools. Earlier fieldwork in north-western Australia had revealed them as surviving only as secret implements used in the male rite of circumcision. Much of this data is still to be published but some results are in print. ${ }^{27} \mathrm{Of}$ widest impact was the demonstration, by Nakako tribesmen, of the 'rolling pressure technique', using a smooth stone to press off the projections remaining from hammer-dressing. Francois Bordes (personal communication) has said that this unrecognised technique seemingly had been in use as far back as Mousterian days in Europe, and that he had, on occasion, unconsciously used it when attempting to replicate ancient tools.

In 1959 H.A. Lindsay was in communication with Norman Blunden and suggested he contact the South Australian Museum to obtain typical artefacts for the collection he was developing. In February 1961 he did so (following correspondence with archaeologists in

Mulvaney 1960.

Tindale 1982 in press (Idaho).

Tindale 1957, Fig. 6.

Tindale 1957.

Tindale 1963 and 1965. 
Chicago) reporting a rock shelter on his station at Noola, near Rylstone, New South Wales, and requesting advice. Having long sought such a shelter this writer visited the site in May of that year and, since Blunden had organised a team of interested helpers, the shelter was excavated to a depth of some three metres and a preliminary report published. ${ }^{28}$ The results have been interpreted as possessing a rich range of microlithic tools for the upper first half to one metre, closely comparable with the tools of the Mudukian of points west, underlain by some two metres of sparser signs of only periodic occupation beginning after a great rock fell out of the roof, perhaps long before a time twelve thousand years ago. These earlier visits were of people using tools clearly related to those found on Tartangan sites so plentiful further west, south west, and north, in Queensland. The excavated section of this rockshelter was published in $1981 .^{29}$ It shows that a single Kartan pebble chopping tool was found in the very bottom of the creviced chamber, undated, but obviously older than the dated hearths above it (Plate 1).

In 1960 a question was raised with this author concerning the possible relationship of the Kartan implements of Australia with the similar pebble tool cultures in Pleistocene Asia. He was led to a conclusion that the earliest home of modern man might well have been in South East Asia, spreading to Australia, to the Americas, and far west towards the Caucasus Mountains and Europe. ${ }^{30}$ Thus he independently reiterated ideas probably first set out by C.O. Sauer. ${ }^{31}$

Interest in the South Australian discoveries of Kartan implements in old soil horizons (indicating such old tool types were significant in the geological history of the Late Pleistocene) was evident during the symposium on Soils, Geochronology and Land Surfaces held in Adelaide in December 1961, under the auspices of the Australian Academy of Science. Participants saw the site at Section 586, Hundred of Willunga with a perched red sand dune site at 165 metres above sea level incorporating Kartan implements. Observers at this conference included F.E. Zeuner of London, who visited the Rainy Creek Pleistocene site on Kangaroo Island, and at Hallett Cove discovered in situ material which he took to London. Figure 4 shows one of his finds. In company with G. Blackburn, J.T. Hutton, Nellie H. Ludbrook, W.T. Ward, and this writer, he viewed eustatic terraces in the south east of South Australia, observing a pre-Mount Gambier eruption Tartangan implement horizon at Mount Gambier and the two beds, widely separated in time (respectively Early Recent, and almost present day) at the Cape Martin site. This had already become, by erosion from fierce Indian Ocean waves, Martin Island.

In October 1962 this writer was flown into the heart of the Arunta (or Simpson) Desert to an archaeological site, discovered by geologist Reginald C. Sprigg, situated 4.5 kilometres west of Geosurvey Hill. Highly patinated large discoidal flint implements of the timari type (Figure 5) were present in soils underlying the present parallel dune system, as well as later in time microlithic implements of types made known in the writings of G.A. Horne and G. Aiston. ${ }^{32}$ The earlier implements were assessed as related to the Tartangan ones of South Australia. There was a brief account of this visit published in the Mail, Adelaide, 3 November 1962.

Shortly afterwards (December 1962) a coastal horizon at Shellharbour, New South Wales, was observed being bulldozed to make a parking area, and a charcoal layer containing pebble end-chopping tools, closely similar to those typical of the most recent occupational sites near Adelaide, was salvaged. It was dated subsequently to c. 140 years ago. ${ }^{33}$

Beginning in 1962 Norman Blunden became a field observer (Plate 1), noting extensive sites being revealed by an agricultural policy in western New South Wales, where chisel-

Tindale 1961 and 1964.

Tindale 1981 , Fig. 11.

Tindale 1960

Sauer 1952.

Horne and Aiston 1924.

Tindale 1964:24. 


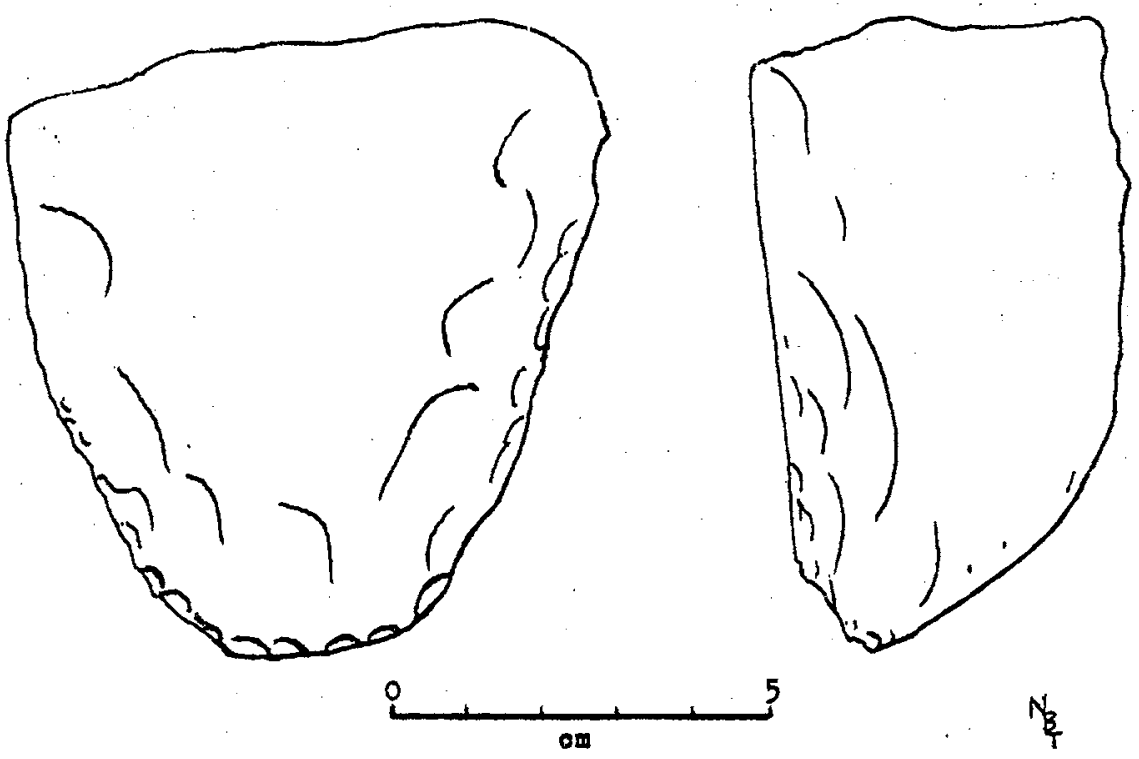

Figure 4. Sketch of Kartan type chopping tool found at Hallett Cove by F.E. Zeuner of London. This extensive Kartan site discovered by H.M. Cooper was one of the earlier ones studied on the Australian mainland. It is the only one to be found close to a glacial period foreshore. There is very deep water close to its present day shoreline.

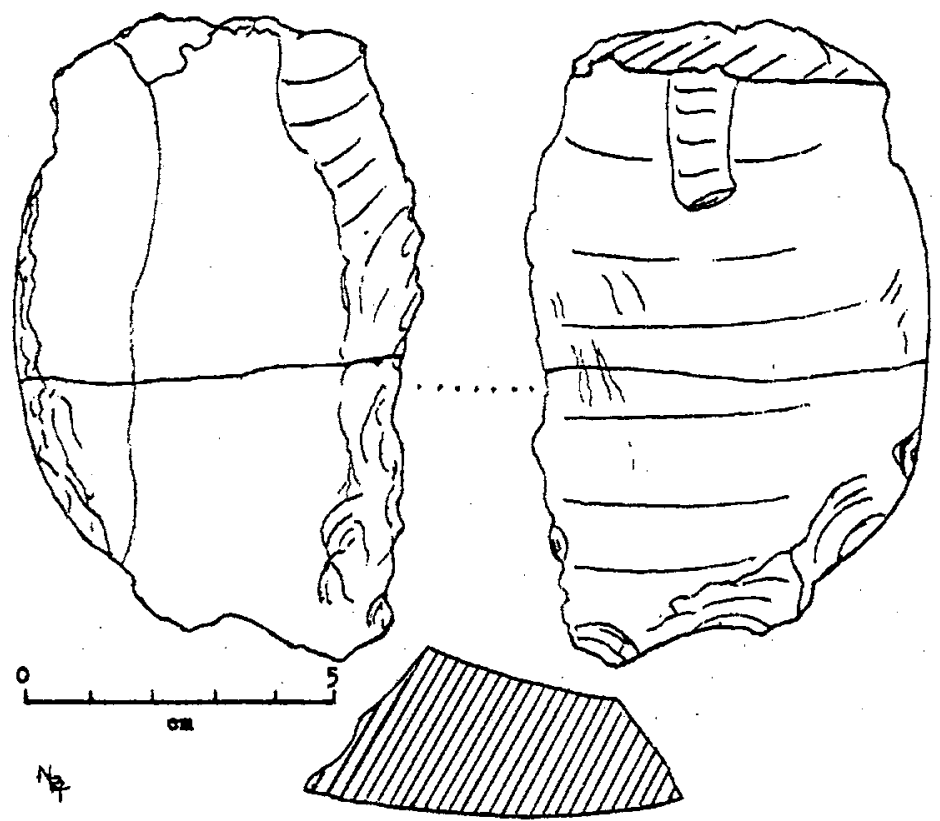

Figure 5. Large tiemari type flake showing roller-pressure secondary trimming on cutting edge. From Site 0 in red soil layer underlying parallel dunes near billabong $4.5 \mathrm{~km}$ west of Geosurvey Hill, Simpson Desert. Specimen was broken across line of section in antiquity and differentially and deeply patinated on reversed faces. Assessed as of Tartangan culture faces. (Specimen A.60728 in South Australian Museum). 
plowing and fertilisers were being used to improve pasture lands. A widespread result was the unearthing of vast numbers of stone tools assessed to be of Kartan types, in areas where there were no signs of the later microlithic culture types but including some tool-like objects, such as the ones locally called 'Bogan picks', and also large well patinated stone axes with hafting grooves, unlike the ones widely associated with post-5000 BP camps. Some of the materials discovered by $N$. Blunden and his daughter June Blunden have been drawn to attention, along with some useful deductions that have been made. ${ }^{34}$ Much remains to be told.

In May 1964 G. Lawton and this writer were able to take J.G.D. Clark of Cambridge and D.J. Mulvaney to see Ngautngaut, and we saw the excavations at Fromms Landing which Mulvaney and Lawton had just completed. ${ }^{35}$ Subsequently, Professor and Mrs Clark collected on the four sites at Moana, and this writer took them by air to Papunya in the Western MacDonnell Ranges, where the Aborigines revealed a mining place for the chlorite schists which have from times past been used in making their stone tjurunga.

In September 1964 David Corbett (Plate 1) led a South Australian Museum party to 'Myrtle Springs' Station on the eastern shore of Lake Torrens. The primary object was to discover meteorites of the type known as australites. These were found to be associated with campsites of the Pirrian culture phase which were abundant in the area of the reported strewn-field, providing a post-shower date for them. ${ }^{36} \mathrm{~A}$ Pirrian horizon was dated at Pine Dam to $1860 \pm 110 \mathrm{BP}$, indicating survival of pirri implements for more than a thousand years there, after disappearance from the Murray River. In the upper Victoria River area as among the Korindji, Ngarinman and Bilingara tribes, far to the northwest, use of such weapon heads survived into modern times indicating the direction of one probable culture shift or change within Australia.

Having retired from his position in the South Australian Museum in 1965 this writer gave a summary account of his developed concept of the culture phases detected in Australia ${ }^{37}$ Following additional studies he submits Figure 6 as a diagrammatic summary of observations to 1980. A later paper, mentioned below as in press in July 1982, gives a possible date for man's presence in Australia much closer to 100,000 years ago.

T.D. Campbell and P.S. Hossfeld in 1966, having long continued their interest in the area, joined with Robert Edwards in studying sites at Mt Burr and at Bevilaqua Cliffs in the south east of South Australia. Key findings included the presence of dingo remains at a date close to 7500 years ago and of another at a level not earlier than $8300 \mathrm{BP}$. The cultural succession they noted was clearly the same as at Cape Martin over a seven thousand year period. A long period of scant occupation in the Mt Burr shelter followed until close to 1000 years ago when microlith impleinent makers were present.

Much other archaeological work has been done in the South Australian area since then and the field has been productive of much evidence on Australian man, so that it might be said that there are only two campsites, one continuous one on the left and another on the right bank of the Murray from Albury to the sea. Roonka, north of Blanchetown, South Australia, received special attention with unprecedented rains on 17 November $1961 \mathrm{Mr}$. Armstrong reported Aboriginal remains exposed and Harry Bowshall, Harold Burrows, and this writer, accompanied by a TV cameraman, found extended burials. A fire had been lit in one grave and its charcoal was preserved for possible radiocarbon dating. A month later Graeme L. Pretty joined the South Australian Museum staff and, realising the potential of the area, started by making observations in a riverbank rock shelter, and then began open air studies. Over the following twenty years his Roonka study has developed as a major one which is providing much information. Reference may be made to one of his later papers

Tindale 1977 and 1981.

Mulvaney, Lawton and Twidale 1964.

Corbett 1967.

Tindale 1968. 
FIGURE 6

SEQUENCE OF STAGES OBSERVED IN AUSTRALIAN PREHISTORY (GENERALISED INTERPRETATION OF N.B. TINDALE, 1980)

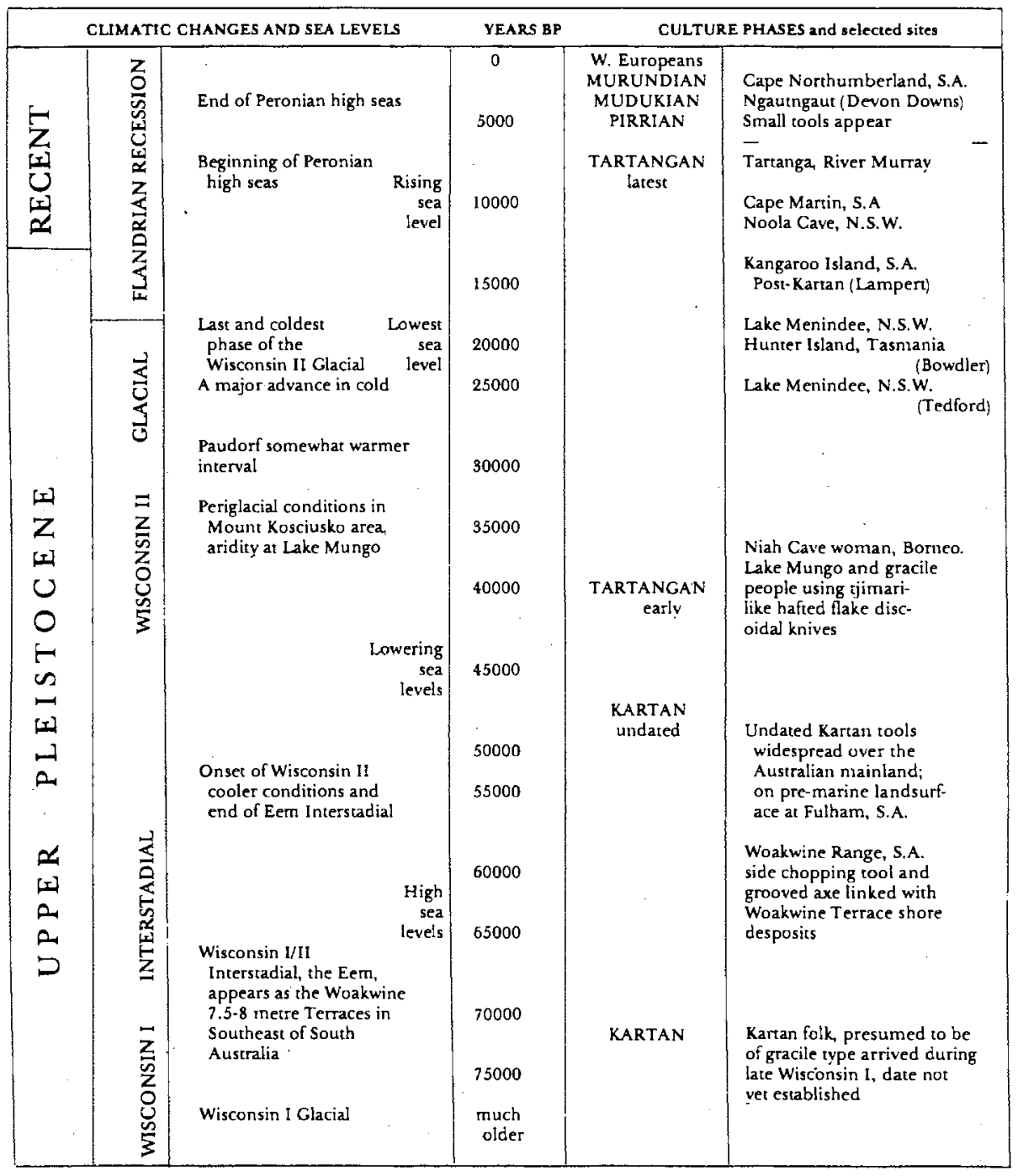


which contains results of considerable importance ${ }^{38}$ He makes interesting comparisons with the sequence of occupational horizons at Tartanga and Ngautngaut, and confirms what had been deduced in the original paper ${ }^{39}$ ie that the Upper Beds were the ones contemporary with the levels in the Ngautngaut rock shelter, actually being separated from the real Tartangan Beds by the water-laid muds now called the Coonambidgal Formation. Pretty had not considered the effect on river level of the Peronian Terrace high seas of the MidRecent which would have affected water levels far upstream beyond Tartanga. It can be deduced that the calcareous hardening of the Tartangan Beds and the mineralization of the bones happened in the progressive risings of water level during late stages of the Flandrian Recession, a point that had been made earlier in a eustatic terrace paper by this author. An important aspect emerges in Pretty's discussion of the Mudukian culture horizon. He indicated that it was originally defined on the basis of the presence of muduk bone toggles which are not always present at other sites. At the time when Ngautngaut was being studied little was known about the geometric microliths, also present. It will be noted that in later studies the geometric microliths have been rightly given the first place in denoting this culture horizon, the separation from the Pirrian coming at a point where they become highly standardised and the pirri projectile point disappears, presumably because of the greater efficiency introduced by the multiple arming of spear heads with such geometrics. Geometrics present in Pirrian horizons are far inferior in skills of manufacture.

Having devoted attention to other facets of his lifework, this writer had less data to offer on the progress of archaeological research linked with South Australia during the 1970 s. When the time comes to chronicle it in full there will be much to tell of the detailed teamwork at Roonka with Graeme Pretty, the peat bog finds of wooden boomerangs and other weapons near Millicent dating back to near the beginning of the Recent Period by Roger Luebbers and his associates, ${ }^{40}$ and the significant excavations on Kangaroo Island which are beginning to reveal the antiquity of the Kartan culture phase and something of post-Kartan days near the end of the Pleistocene, findings which we owe to Ronald J. Lampert ${ }^{41}$ There has been systematic and dedicated work by members of the Anthropological Society of South Australia, as instanced by the recently completed survey of the Waldeila site south of Adelaide by R.D.J. Weathersbee, and the continuing work at Moana being carried out by Valerie M. Campbell and other members.

What of the future? In 1968 I reported a find of a transported basaltic side-pebble chopping tool of classical Kartan type which had been dug up by Tom McCourt from the foreshore deposits of the Woakwine eustatic terrace, inland from Beachport, South Australia. This find is now supported by the ploughing up on the same eustatic terrace foreshore near by of a large grooved axe of the type thought to be associated with Kartan sites in western New South Wales. It is also in the McCourt Collection. ${ }^{42}$

This paper is based on the Presidential address given to Section 25A (Archaeology) at the ANZAAS Jubilee Congress, Adelaide, May 1980. Shortly after the address was given von der Borch and his associates ${ }^{43}$ published dates for the Woakwine terrace based on an amino acid racemization technique which made possible further study of the time factor. Their date of 92,000 BP for a site enabled the writer to consider the possibility that man was already established in southern Australia by that time and that his arrival could have been at a time closer to 100,000 years ago than had previously been suspected. A paper on the significance of Woakwine implements, also confirming finds of Kartan implements in all parts of Australia, was read before a conference at Scripps Institution of Oceanography in October 1981.4

PALO ALTO, CALIFORNIA

Pretty 1977

Hale and Tindale 1930.

Luebbers 1975:39.

Lampert 1981 .

Tindale 1968:639 and McCourt 1975:15.

von der Borch and others 1980.

Tindale 1982 in press (Scripps paper). 


\section{BIBLIOGRAPHY}

von der Borch, C.C., Bada, J.L. and Schwebel, D.L. 'Amino acid racemization dating of late Quaternary strandline events of the coastal plain sequence near Robe, southeastern South Australia', Transactions of the Royal Society of South Australia, 104(5/6), 1980: 167-170.

Campbell, T.D., Cleland, J.B. and Hossfeld, P.S. 'Aborigines of the lower south-east of South Australia', Records of the South Australian Musetm, 8(3), 1946:445-502.

Campbell, T.D., Edwards, R and Hossfeld, P.S. Archaeological excavations in the south-east of South Australia MS, 1966 [AIAS MS 479].

Corbett, David W.P. 'Australites from Myrtle Springs Station, South Australia', Records of the South Australian Museum, 15(3), 1967:561-574

Gallus, A. 'Results of the exploration of Koonalda Cave, 1956-1968', in Wright, R.V.S. ed. Archaeology of the Gallus site, Koonalda Cave. Canberra, 1971:87-133.

Hale, Herbert M. and Tindale, Norman B. 'Notes on some human remains in the lower Murray Valley, South Australia', Records of the South Australion Museum, 4(2), 1930:145-218.

Horne, G. and Aiston, G. Savage life in central Australia. London, 1924.

Howchin, Walter. 'Further notes on the geology of Kangaroo Island', Transactions and Proceedings of the Royal Society of South Australia, 27(1), 1903:75-90.

- 'Supplementary notes on the occurrence of Aboriginal remains discovered by Captain S.A. White at Fulham ..., Transactions and Proceedings of the Royal Society of South Australia, 43(1), 19 19:81-84.

- Stone implements of the Adelaide tribe of Aborigines, now extinct. Adelaide, 1934.

Lampert, R.J. 'Kangaroo Island and the antiquity of Australians', in Wright, R.S.V. ed. Stome tools as cultural markers: change, evolution and complexity. Canberra, 1977:213-218.

- The great Kartan mystery. (Terra Australis 6.) Canberra, 1981.

Luebbers, R.A. 'Ancient boomerangs discovered in South Australia', Nature, 253(5486), 1975:39.

McCourt, Thomas. Aboriginal artefacts. Adelaide, 1975.

Mitchell, S.R. Stone-age craftsmen: stone tools and camping places of the Australion Aborigines. Melbourne, 1949.

Mulvaney, D.J. 'Archaeological excavations at Fromm's Landing on the Lower Murray River, South Australia', Proceedings of the Royal Society of Victoria, 72(2), 1960:53-85.

The prehistory of Australia. Ringwood, 1975

Mulvaney, D.J., Lawton, G.H. and Twidale, C.R 'Archaeological excavation of rock shelter 6, Fromm's Landing, South Australia', Praceedings of the Royal Society of Victoria, 77(2), 1964:479-516.

Pretty, Graeme L. 'The cultural chronology of the Roonka Flat: a preliminary consideration', in Wright, R.S.V. ed. Stone tools as cultural markers. Canberra, 1977:288-331.

Sauer, C.O. Agricultural origins and dispersals. New York, 1952.

Sheard, Harold L. 'Aboriginal rock carvings at Devon Downs, River Murray, South Australia', Transactions and Proceedings of the Royal Saciety of South Australia, 51, 1927:18-19.

Stapleton, P. de S. 'Aboriginal relics . . . rock carvings [and] ... stone structures', South Australian Naturalist, 12(2), 1931:21-24.

— 'Bifaced stone implements from south-eastern South Australia', Records of the South Australian Musetsm, 8(2), 1945:281-287.

Tedford, Richard $\mathrm{H}$. The fossil Macropodidae from Lake Menindee, New South Wales. (University of California Publications in Geological Sciences 64.) Berkeley, 1967.

Tindale, N.B. 'Native burial at Pedler's Creek, South Australia', South Australian Naturalist, 8(1), $1926: 10$.

- Relationship of the extinct Kangaroo Island culture with cultures of Australia, Tasmania, and Malaya', Records of the South Austratian Museum, 6(1), 1987:39-60.

- 'Subdivision of Pleistocene time in South Australia', Records of the South Australian Museum, 8(4), 1947:619-652.

- Archaeological site at Lake Menindee, New South Wales', Records of the South Australion Museum, $11(3), 1955: 269-298$.

— 'Culture succession in south-eastern Australia from late Pleistocene to the present', Records of the South Australian Museum, 13(1), 1957:1-49.

- 'A dated Tartangan implement site from Cape Martin, south-east of South Australia', Transactions of the Royal Society of South Australia, 80, 1957:109-123.

- 'Man of the hunting age', Colorado Quarterly, 8(3), 1960:229-245.

- 'Archaeological excavation of Noola rock shelter. a preliminary report', Records of the South Australian Museum, 14(1), 1961:193-196.

- 'Totemic beliefs in the Western Desert of Australia. Part 2. Musical rocks and associated objects of the Pitjandjara people', Records of the South Australion Musetum, 14(3), 1963:499-5 \4.

- 'Radiocarbon dates of interest to Australian archacologists', Australian Joumal of Science, 27(1), 1964:24.

- 'Stone implement making among the Nakako, Ngadadjara and Pitjandjara of the Great Western Desert', Records of the South Australian Musetum, 15(1), 1965:131-164.

- Nomenclature of archaeological cultures and associated implements in Australia', Records of the South Australian Museum, 15(4), 1968:615-640. 
- 'Adaptive significance of the Panara or grass seed culture of Australia', in Wright, R.S.V. ed Stone tools as cultural markers. Canberra, 1977:345-349.

- 'Prehistory of the Aborigines, some interesting considerations', in Keast, Allen ed Ecological biogeography of Australia. The Hague, 1981:1761-1797.

'The Woakwine Terrace in the southeast of South Australia and indications of the very early presence of man'. (Scripps Institution of Oceanography, October 1981.) 1982 (in press).

'Australian Aboriginal techniques of pressure-flaking stone implements-some personal observations'. (University of Idaho.) 1982 (in press).

Tindale, Norman B. and Maegraith, Brian G. 'Traces of an extinct Aboriginal population on Kangaroo Island', Records of the South Australian Museum, 4(3), 1931:275-289.

Tindale, Norman B. and Mountford, C.P. 'Results of the excavation of Kongarati Cave, near Second Vallev, South Australia, Records of the South Australian Museum, 5(4), 1936:487-502.

Tindale, Norman B. and Noone, H.V.V. 'Analysis of an Australian Aboriginal's hoard of knapped flint', Transactions of the Royal Society of South Australia, 65(1), 1941:116-122.

White, S.A. 'Notes on the occurrence of Aboriginal remains below marine deposits at the Reedbeds, Fulham, near Adelaide', Transactions and Proceedings of the Royal Society of South Australia, 43, 1919:7780. 